\title{
Behavior of horizontal sub-surface flow wetlands as an alternative for the wastewater treatment contaminated with florfenicol
}

\section{Comportamiento de los humedales horizontales de flujo subsuperficial como alternativa para el tratamiento de las aguas residuales contaminadas con florfenicol}

\author{
Diana C. Rodriguez ${ }^{1 \S}\left(\mathbb{D}\right.$, Mary A. Cardona $^{1}\left(\mathbb{D}\right.$, Gustavo Peñuela $^{1}(\mathbb{D})$ \\ ${ }^{1}$ Universidad de Antioquia, Facultad de Ingeniería, Escuela Ambiental, Grupo de Diagnóstico y \\ Control de la Contaminación (GDCON), Medellin, Colombia \\ §diana.rodriguez@udea.edu.co,maleja2290@gmail.com,gustavo.penuela@udea.edu.co
}

Recibido: 13 de mayo de 2020 - Aceptado: 23 de septiembre de 2020

\begin{abstract}
In recent years, the increase in the use and production of antibiotics for the protection of animals has been associated not only with human health problems due to bacterial resistance, but also with environmental problems, which have led to the deterioration of the water resources, since a large part of these are discharged into the environment without any type of treatment. This situation has highlighted the fact that a large part of the antibiotics are not efficiently removed in conventional wastewater treatment plants, being necessary to implement efficient and low-cost treatment alternatives. The evaluation of the removal of the antibiotic florfenicol was carried out using pilot horizontal subsurface flow wetlands, with a hydraulic retention time of $4.2 \mathrm{~d}$, planted with macrophytes (Phragmites australis) and using concentrations of $10,15,20$ and $25 \mathrm{mg} / \mathrm{L}$ of florfenicol. It was concluded that the removal of the antibiotic and the COD was decreasing over time, with a maximum removal percentage of $77.9 \%$ of florfenicol and $85.2 \%$ of COD during the first days of exposure. The results found allowed to demonstrate that florfenicol was not retained in the granular material of the wetlands, even in the macrophytes and that the predominant removal mechanism was biological degradation.
\end{abstract}

Keywords: Antibiotics, Degradation, Inhibition, Treatment systems.

\section{Resumen}

En los últimos años, el aumento en el uso y producción de antibióticos para la protección de los animales se ha asociado no solo con problemas a la salud humana debidos a la resistencia bacteriana, sino también con problemas ambientales, que han llevado al deterioro de los recursos hídricos, ya que gran parte de estos son descargados al 
ambiente sin ningún tipo de tratamiento. Esta situación ha dejado en evidencia, el hecho de que gran parte de los antibióticos no son removidos eficientemente en las plantas de tratamiento de aguas residuales convencionales, siendo necesario la implementación de alternativas de tratamiento eficientes y de bajo costo. Se realizó la evaluación de la remoción del antibiótico florfenicol utilizando humedales horizontales piloto de flujo subsuperficial, con un tiempo de retención hidráulica de $4.2 \mathrm{~d}$, plantados con macrófitas (Phragmites australis) y empleando concentraciones de 10, 15, 20 y $25 \mathrm{mg} / \mathrm{L}$ de florfenicol. Se concluyó que la remoción del antibiótico y de la DQO fue decreciente a lo largo del tiempo, con un porcentaje de remoción máximo de $77.9 \%$ de florfenicol y $85.2 \%$ de DQO durante los primeros días de exposición. Los resultados encontrados, permitieron demostrar que el florfenicol no quedó retenido en el material granular de los humedales, ni en las macrófitas y que el mecanismo de remoción predominante de remoción fue la degradación biológica.

Palabras claves: Antibióticos, Degradación, Inhibición, Sistemas de tratamiento.

\section{Introduction}

In the last decades, there has been an increase in the production of the pharmaceutical industry due to the strong demand exerted by human and veterinary medicine, which has generated that more and more amounts of antibiotic residues are found in wastewater and natural ${ }^{(1)}$, because these drugs are excreted and later transported to receiving water sources. Although at present the full effects of these drugs on aquatic ecosystems and for human health are not known, it has been shown that, although these drugs are found at trace levels in different water sources, they can generate persistence chemistry, microbial resistance, and synergistic effects as a consequence of the numerous antibiotics present (2).

The global market for animal antibiotics and antimicrobials is estimated to grow at a compound annual rate of $4.6 \%$ from 2016 to 2021 to reach USD 4.73 billion by $2021^{(3)}$. Because antibiotics pass through the animal and end up in manure, animal production farms are a major source of environmental contamination with resistant antibiotics and bacteria. The use of antibiotics in animals is not the problem, it is their abuse, since in the whole world up to four times more doses of antibiotics are applied to animals than humans and in many cases animals are subjected at high doses of antibiotics, even if they are not sick, this as a preventive measure ${ }^{(4)}$.
The wide range of applications and the type of diseases treated make phenicols, such as florfenicol, extremely important agents for veterinary medicine, being used as an antibiotic for poultry, cattle, goats, equines, rabbits, sheep, fish and swine ${ }^{(5)}$. Florfenicol is characterized as a broad spectrum bacteriostatic, effective against various fish pathogens and control of bacterial infections of the respiratory tract in cattle and pigs ${ }^{(6)}$. This drug is characterized by high bioavailability, good tissue penetration, and rapid clearance ${ }^{(7)}$. Finally ending in various water sources.

In Colombia there are controls regarding the use of antibiotics as growth inducers in the pig and livestock industry, however, regarding the commercialization of antibiotics for veterinary use, there are no restrictions, so in some cases the supply is empirical and without formulation of the veterinarian. Likewise, there are many fish farming centers to market a great variety of fish, and in which several antibiotics are used, including florfenicol ${ }^{(4)}$.

Oxytetracycline and florfenicol are two of the most widely used antibiotics for the control of bacterial diseases in fish ${ }^{(8-11)}$, Carraschi et al. ${ }^{(8)}$ monitored florfenicol in 8 effluents from animal farms, 18 river water samples, and 8 fish pond water samples, detecting averages of $0.95,2.40$, and $2.84 \mu \mathrm{g} / \mathrm{L}$, respectively. As the waters of the ponds of the fish farming centers carry 
florfenicol residues that are dumped into rivers, the environmental authorities in Colombia require these fish farms to treat these waters, with the advantage that the vast majority of fish farms are in rural areas, where they have extensive lands, which facilitates the treatment of these waters with subsurface constructed wetlands. It has been shown that some antibiotics are not totally removed from wastewater treatment plants with primary treatments, since a great variety of drugs have been detected in the effluents of these plants in the order of $\mathrm{ng} / \mathrm{L}$ to $\mathrm{mg} / \mathrm{L}^{(12)}$. Because of this, the removal of these drugs depends on the implementation of secondary and tertiary treatment. One of these mechanisms corresponds to artificial wetlands, which are effective, lowcost, simple-to-use treatment systems that have shown high removal of pharmaceutical products (13-15) and have additionally been used for water treatment. fish farm residuals ${ }^{(15,17)}$.

The present study evaluated the behavior and inhibition processes of microorganisms in the removal of florfenicol and organic matter, using horizontal flow subsurface wetlands at a pilot level, through an analysis of physicochemical parameters in the tributary and effluent, in situ parameters, microbiological and adsorption analysis on both gravel and planted plant material.

\section{Methodology}

\subsection{Subsurface horizontal wetlands}

Five horizontal subsurface flow wetlands (HSFS) were used (Figure 1), constructed of fiberglass tanks with dimensions of $0.6 \mathrm{~m}$ wide $\mathrm{x}$ $0.6 \mathrm{~m}$ high $\times 1.0 \mathrm{~m}$ long and a water depth of $0.30 \mathrm{~m}$. A layer of gravel from $1 / 4$ "to $1 / 8$ " was used, with a uniformity coefficient $<1.70$ and a specific gravity of 2.5 , and piezometers were installed both at the beginning and at the end of each module to take samples of gravel and to perform microbiological analysis of the biofilm. The wetlands were planted with the macrophyte Phragmites australis and supplied with synthetic wastewater and different concentrations of florfenicol (FLO) continuously using a flow rate of $6.3 \mathrm{~cm}^{3} / \mathrm{min}$ controlled with flow meters and a hydraulic retention time (HRT) $4.2 \mathrm{~d}$.

The composition of the synthetic water was calculated according to the formula proposed by Dangcong et al. ${ }^{(18)}$, to simulate wastewater at the laboratory level. The final proportions were; $0.25 \mathrm{~g} / \mathrm{L} \mathrm{C}_{6} \mathrm{H}_{2} \mathrm{O}_{6}, 0.16 \mathrm{~g} / \mathrm{L} \mathrm{NH} \mathrm{NCl}_{4}$ and $0.03 \mathrm{~g} / \mathrm{L}$ $\mathrm{KH}_{2} \mathrm{PO}_{4}$. The $\mathrm{pH}$ in the tributary was maintained in a range of 6.5 to 7.5 , by adding $\mathrm{HCO}_{3}$. The research was carried out in the Pollution Diagnosis and Control Group (GDCON), belonging to the Faculty of Engineering of the University of Antioquia, located at the University Research Headquarters (SIU) in the city of Medellín.

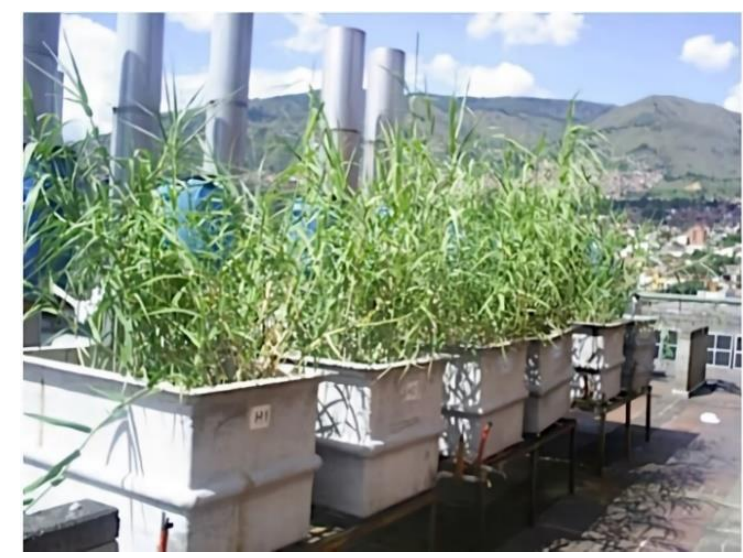

Figure 1. Subsurface flow pilot wetlands installed at the University Research Headquarters (SIU)

\subsection{Collection of experimental data}

The start-up and stabilization time of the wetlands was 10 days; during which microbiological heterotrophs were sowed to evaluate the growth of microorganisms and determine the end time of stabilization, on the tenth day an important growth of these was evidenced to start the antibiotic removal process. 
During the start-up and acclimatization period, only synthetic water without the presence of florfenicol was supplied for the five wetlands.

After the acclimatization period, FLO concentrations were supplied to each wetland, for a period of 30 days, using values of 10, 15, 20 and $25 \mathrm{mg} / \mathrm{L}$ for wetlands H1, H2, H3 and H4 respectively and only water synthetic $(0 \mathrm{mg} / \mathrm{L}$ FLO) for the H5 wetland used as target, additionally, this last wetland only operated with gravel, without the presence of planted macrophytes, in order to determine if the vegetation had an impact on the degradation processes of organic matter and the effect of other variables analyzed. Samplings were carried out every two days, both in the affluent and in the effluent of each of the installed wetlands in order to evaluate their behavior and the efficiencies in the removal of both organic matter and the antibiotic. All analyzes were carried out in the laboratory of the GDCON group, an accredited laboratory for water analysis by IDEAM under the NTC-ISO / IEC 17025 standard, Resolution 1665 of July 12, 2011.

\subsection{Physicochemical analysis}

For the analysis of the in situ parameters, a WTW 3210 conductivity meter was used to measure the electrical conductivity (EC) and a WTW $\mathrm{pH} 7110 \mathrm{pH}$ meter to read the $\mathrm{pH}$ and the Redox Potential (ORP). Additionally, the physicochemical parameters of Chemical Oxygen Demand (COD), Turbidity and Total Alkalinity (TA) were analyzed, following the analytical criteria of the Standard Methods ${ }^{(19)}$.

\subsection{Analysis by liquid chromatography}

For the analysis of florfenicol (FLO), a 11001200 high-efficiency liquid chromatograph with diode array detector (Agilent Technologies) was used. The separation was performed on an analytical ultra IBD column $150 \times 4.6 \mathrm{~mm}$ and 5 $\mu \mathrm{m}$ film thickness (Restek). The analytical column was kept at $30^{\circ} \mathrm{C}$ and the mobile phase was: solvent A (acetonitrile: methanol 9:1 at $0.1 \%$ in trichloroacetic acid) and solvent B (water grade HPLC at $0.1 \%$ in trichloroacetic acid), with a gradient that started with $60 \%$ of solvent B and $40 \%$ of solvent A, at 4 min; $40 \%$ of solvent B and $60 \%$ of solvent A. At a flow of $1.5 \mathrm{~mL} / \mathrm{min}, 50 \mu \mathrm{L}$ of sample was injected, and the diode array detector was used at $230 \mathrm{~nm}$. The retention time of the FLO was 2.020 minutes. The quantification of the antibiotic was established through a calibration curve performed at concentrations of 5, 10, 15, 20, 25 and $30 \mathrm{mg} / \mathrm{L}$.

The calculation of the removal efficiency of florfenicol was carried out using Eq. 1. Where, [FLO]iy $[F L O] e$ correspond to the concentration of the FLO in the influent and in the effluent, respectively.

$$
\% R=\frac{[[F L O] \mathrm{i}-[F L O] e]}{[F L O] i} * 100 \quad \text { Eq. } 1
$$

\subsection{Microbiological analysis}

For the microbiological analyzes, angeo bags packed with gravel were used located inside the piezometers (PVC tube perforated along the length) installed inside each wetland (Figure 2). 10 grams of the gravel extracted from the piezometers were taken and $90 \mathrm{~mL}$ of $0.9 \%$ saline solution $(\mathrm{NaCl})$ were added, then they were placed in an ultrasound equipment (Elma, Ultrasonic LC $60 \mathrm{H}$ ), where the biofilm adhered to the gravel was laid off. The presence of heterotrophs in the gravel at the entrance and exit of each of the wetlands was evaluated, using the membrane filtration method with Plate Count Agar incubated for 48 hours at $35^{\circ} \mathrm{C} \pm 0.5^{\circ} \mathrm{C}$. 


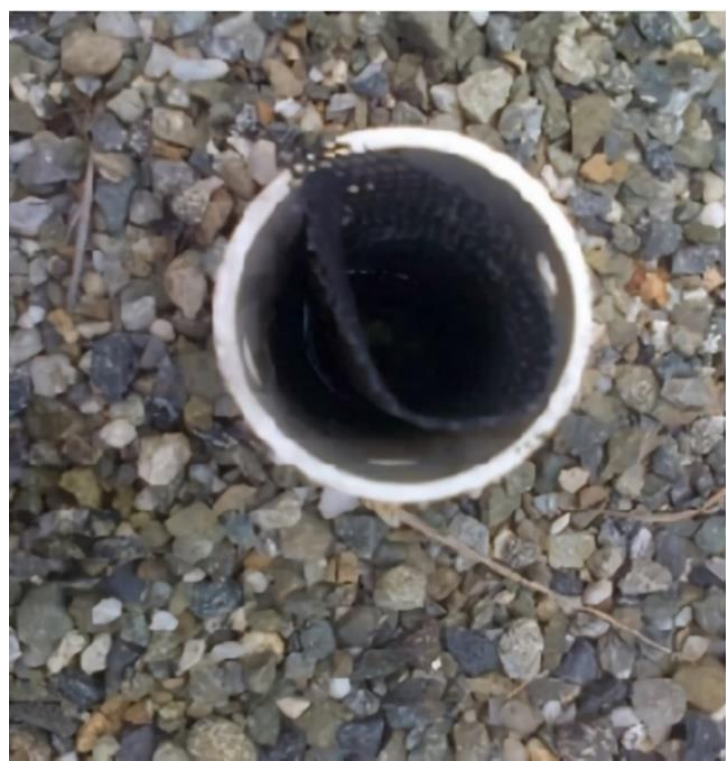

Figure 2. Piezometer and angeo bag inside the wetland

\subsection{Inhibition test}

The inhibition test was performed following the protocol described by Londoño et al. (20). Concentrations of 10, 15, 20 and $25 \mathrm{mg} / \mathrm{L}$ of FLO were prepared and an inhibition test was performed using Staphylococcus aureus ATCC 6538 (F3) (facultative bacteria) in nutrient agar and incubated at $35^{\circ} \mathrm{C} \pm 0.5$ for 24 hours, then a phosphate buffer solution was clouded with the bacteria until it reached 0.5 on the Mcfarland scale. A swab was taken and immersed in the bacterial solution, draining the excess, turning the swab inside the tube, then covered in the Müller Hinton culture medium, making the bacteria evenly distributed on the Agar. After having the bacteria on the agar, two holes were made with the help of a previously sterilized punch. The sample was shaken vigorously and approximately $100 \mu \mathrm{L}$ was taken into a syringe. This sample was filtered with a $0.45 \mu \mathrm{m}$ nylon acrodisc and deposited in each of the wells made. The growth control of the procedure was a S. aureus strain in Müller Hinton, an environmental control that was carried out by opening a petri dish with culture medium in the laminar flow chamber for the duration of the procedure and a negative control using distilled water. All boxes were incubated at a temperature of $35^{\circ} \mathrm{C} \pm 0.5$ for $24 \mathrm{~h}$. After the incubation time, the inhibition diameter was measured, evidenced by the presence of a halo in which no bacterial growth was obtained.

\subsection{Analysis in plant material}

At the end of the experiments, a homogenization of the plant material of each of the wetlands that had contact with the FLO was carried out, divided into three segments: leaves, stem and roots, in order to analyze if the FLO was retained in any of the parts of the macrophytes, according to the methodology defined by Usuga et al. ${ }^{(21)}$. To extract this antibiotic, 3 grams of each sample were taken in a $50 \mathrm{~mL}$ falcon tube and $10 \mathrm{~mL}$ of HPLC grade methanol were added, and it was stirred for 5 minutes. Later, tests were performed using the dSPE (Dispersive solid phase extraction) technique ${ }^{(22)}$, with different cleaning methods. As a result, the best cleaning method was the one that contained $25 \mathrm{mg}$ of PSA (for its acronym in English Primary Secondary Amine) and $150 \mathrm{mg}$ of $\mathrm{MgSO}_{4}$, with average recovery percentages of $81.6 \%$. The final extract was analyzed using a liquid chromatograph following the previously described methodology.

\subsection{Statistical analysis}

To observe the variation over time of the different parameters analyzed with the different wetlands, an exploratory analysis of the data, box and whisker plots, and correlations between the variables studied was performed. Results are represented as the mean \pm standard deviation. Statistical analysis was performed using $R$ software version 3.1.1.

\section{Results and discussion}

\subsection{Behavior of physicochemical parameters}

$\mathrm{pH}$ in biological systems is an important parameter because microorganisms have $\mathrm{pH}$ ranges where their development and growth are optimal, this value has been reported between 
6.5-7.5 ${ }^{(23)}$, where values below 5.0 or above 8.0 usually inhibit the metabolism of microorganisms. In Figure 3a, behavior of the $\mathrm{pH}$ in the effluent of the 5 wetlands is shown, in this case, none of the $\mathrm{pH}$ values were below 5.0 or above 8.0 , however, the $\mathrm{pH}$ ranges in the wetlands oscillated between 6.4 to 7.0 for wetlands $\mathrm{H} 1, \mathrm{H} 2, \mathrm{H} 3$ and $\mathrm{H} 4$ and for $\mathrm{H} 5$ it ranged between 7.3 to 7.6 showing a lower variation in $\mathrm{pH}$ in the wetland without plants and without antibiotics (H5) and in the other wetlands found a greater variation in $\mathrm{pH}$ and additionally lower ranges, indicating that not only the plants affect the dynamics of this parameter, but also the load of the applied antibiotic, with acidification processes predominant. In the case of vegetation, it affects the physicochemical parameters of the wetland due to the fact that cellular respiration processes increase where there is a greater consumption of $\mathrm{CO}_{2}$ and therefore a greater release of oxygen into the atmosphere ${ }^{(24)}$, where by action of the aerenchyma; tissue through which oxygen is transported from the aerial parts to the root ${ }^{(25)}$, some diffusion of oxygen towards the roots can occur (26), a phenomenon that favors the metabolism of aerobic bacteria, which take advantage of the available $\mathrm{O}_{2}$ to degrade organic matter to $\mathrm{CO}_{2}$, water and other inorganic compounds.

Alkalinity is an indicator of the buffering capacity of water to neutralize acids and is due to the presence of various components such as hydroxides, carbonates and bicarbonates. For this parameter, both the target (H5) and the rest of the wetlands ( $\mathrm{H} 1$ to $\mathrm{H} 4)$, had a similar behavior (Figure 3b), with values that ranged from $152.1 \mathrm{mg}$ of $\mathrm{CaCO}_{3} / \mathrm{L}$ to $210.2 \mathrm{mg}$ of $\mathrm{CaCO}_{3} / \mathrm{L}$ ( $\mathrm{p}>0.05$ ). Alkalinity values increased in the last days of operation of all wetlands (from day 18), a situation that could be due to the adaptation of microorganisms and the balance and synergy between the $\mathrm{CO}_{2}$ consumed by the plants and the $\mathrm{CO}_{2}$ released by microorganisms.

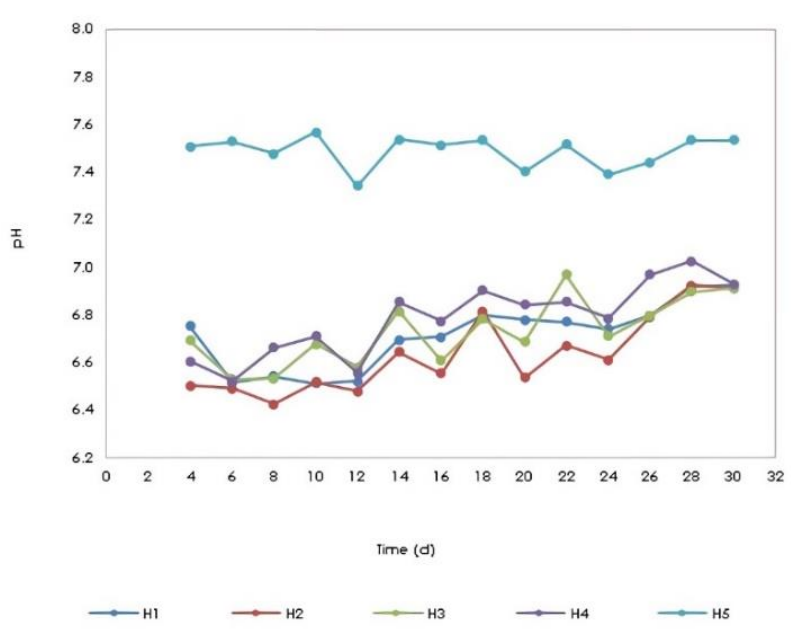

(a)

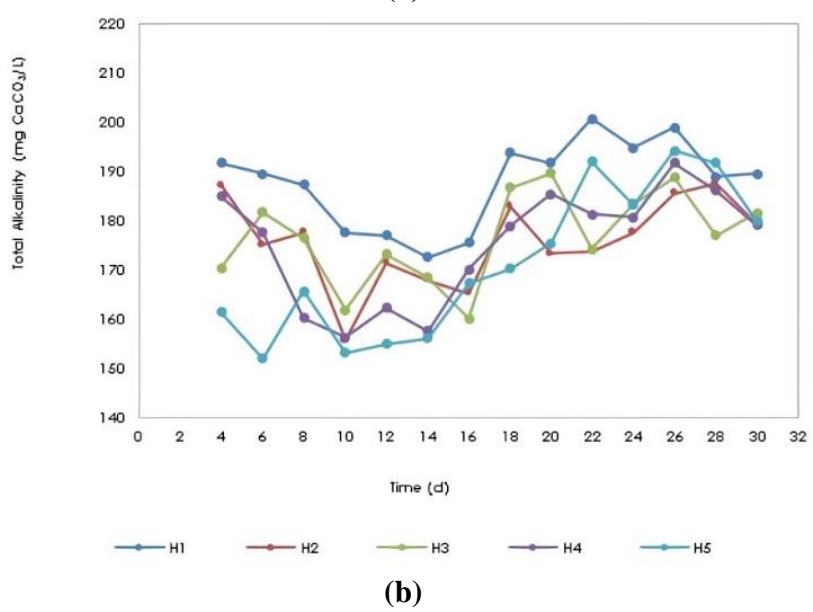

Figure 3. Behavior of $p H$ and alkalinity in the effluents from wetlands. a) $\mathrm{pH}$. b) Total Alkalinity

The redox potential is a measure of the activity of electrons. Any system with a high magnitude positive redox potential value (accepts electrons) is indicative of an environment that favors oxidation reactions. Also, a low magnitude negative redox potential value (donates electrons) is indicative of a highly reducing environment. Oxidation and reduction reactions regulate the behavior of many chemical compounds present in natural water bodies, in addition, the redox potential affects the distribution and metabolic activity of microorganisms.

Figure 4 shows the variation of the redox potential in the effluent of the different wetlands, where variations were found between +282.30 
$\mathrm{mV}$ and $-34.12 \mathrm{mV}$ and with average values of $+153.66 \mathrm{mV}$ for $\mathrm{H} 1,+162.94 \mathrm{mV}$ for $\mathrm{H} 2$, $+115.92 \mathrm{mV}$ for $\mathrm{H} 3,+130.74 \mathrm{mV}$ for $\mathrm{H} 4$ and $+189.47 \mathrm{mV}$ for $\mathrm{H} 5$, where the redox potentials were higher for wetlands with lower loads of florfenicol (H1, H2) and without florfenicol (H5), the latter being the highest average ORP found.

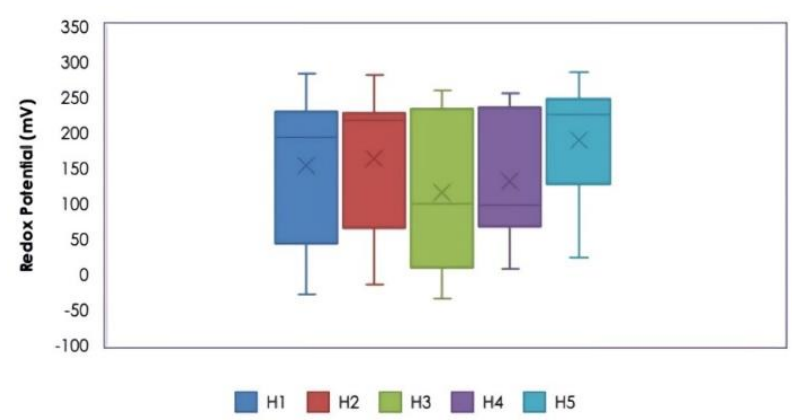

Figure 4. Behavior of the redox potential in the effluents of wetlands

Although there was no statistically significant difference $(p>0.05)$, between each evaluated florfenicol load and the redox potential, the ORP values were slightly lower for the highest florfenicol concentrations (20 and $25 \mathrm{mg} / \mathrm{L}$ ), where denitrification processes (anoxic) could occur with nitrates as electron acceptors, this situation may be related to the molecular structure of florfenicol $\left(\mathrm{C}_{12} \mathrm{H}_{14} \mathrm{Cl}_{2} \mathrm{FNO}_{4} \mathrm{~S}\right)$ which contains nitrogen, therefore, the higher the concentration of florfenicol in the medium, would expect a higher concentration of organic nitrogen due to the breakdown of the molecule during the degradation process, which would favor nitrification processes in a first aerobic stage and later denitrification in an anoxic stage with a decrease in oxygen present, which would explain the redox potential values found.

Denitrification is a heterotrophic anaerobic respiratory process of the anoxic type, where the reduction of nitrate to $\mathrm{N} 2$ follows a series of steps that involve the activity of different enzymes. This process originates after the ammonium is oxidized to nitrate, then the latter is reduced to N2 (nitrogen gas) ${ }^{(27)}$.

Electrical conductivity is the measure of the ability of water to conduct electricity, which is due to ions in solution, therefore, increasing the concentration of ions causes an increase in conductivity. In the wetlands, the electrical conductivity in the tributary (Figure 5a) and the effluent (Figure 5b) was monitored and it was evidenced that the electrical conductivity in the effluent of all monitored wetlands was higher than in the tributary, where the conductivity it ranged between $179.80 \mu \mathrm{S} / \mathrm{cm}$ and 126.20 $\mu \mathrm{S} / \mathrm{cm}$ and that of the effluent between 558.00 $\mu \mathrm{S} / \mathrm{cm}$ and $362.00 \mu \mathrm{S} / \mathrm{cm}$. This increase could be due to the degradation process of organic compounds from synthetic wastewater and florfenicol, which due to biological degradation give rise to the formation of soluble inorganic species, which increase electrical conductivity.

Florfenicol contains chlorine, phosphorus, nitrogen and organic sulfur in its molecule, which, when undergoing a biological degradation process, give rise to the formation of chloride, fluoride, ammonium and sulfate ions, and that is why the H5 wetland, which no antibiotic was added, it presented a lower electrical conductivity (absence of the ions from florfenicol mineralization) in the effluent than that of the other wetlands.

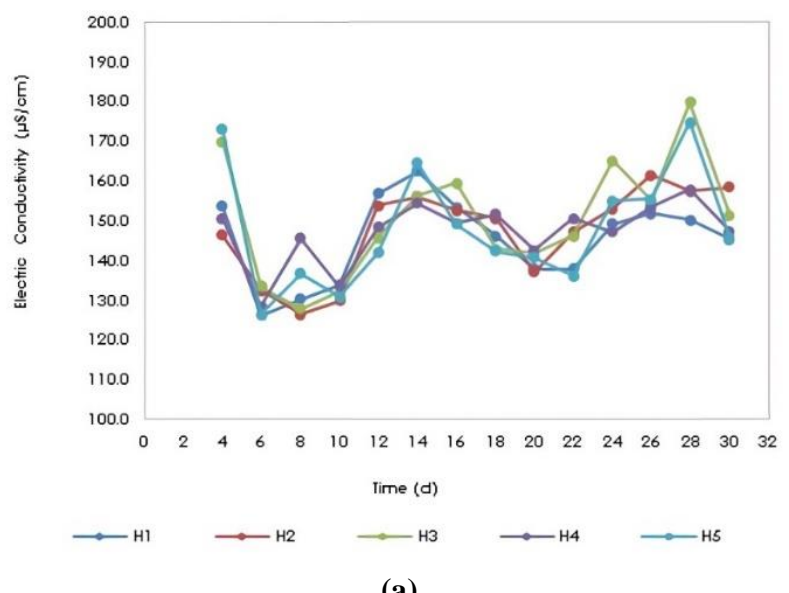

(a) 


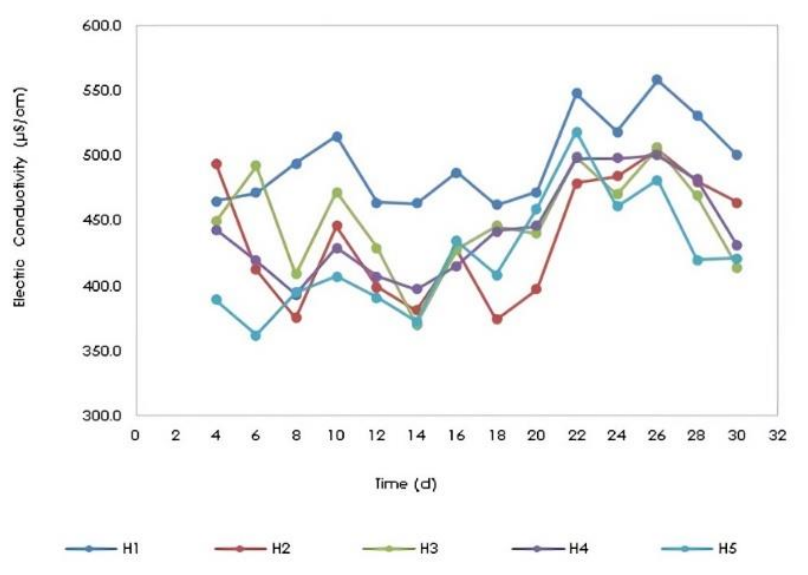

(b)

Figure 5. Behavior of conductivity in wetlands. a) Influent. b) Effluent

The turbidity in the effluents of wetlands H1, $\mathrm{H} 2, \mathrm{H} 3, \mathrm{H} 4$ varied significantly compared to wetland H5 (Figure 6). This could be a consequence of the presence of the plants (Phragmites australis) in the $\mathrm{H} 1$ to $\mathrm{H} 4$ wetlands and not because of the presence of the antibiotic, since the turbidity is affected by the suspended solids and/or colloids, which can be contributed by the plant roots. Turbidity ranged from 0.92 NTU as the minimum value for $\mathrm{H} 5$ to 26.30 NTU as the maximum value for $\mathrm{H} 3$.

\subsection{Variation of removal percentages}

Removal percentages were calculated for both COD (Figure 7a) and florfenicol (Figure 7b) for each of the wetlands, in which a decreasing removal behavior was evidenced over time, with the exception of the $\mathrm{H} 5$ wetland (Control), where the COD removal was constant throughout the monitoring time.

The COD is made up of 2 fractions; one corresponding to the biodegradable fraction (determined as $\mathrm{BOD}_{5}$ ) and the other nonbiodegradable. The one that is removed in a wetland by microorganisms is the biodegradable one, but the non-biodegradable fraction could also be removed by precipitation, adsorption processes (on gravel and plant roots) and by absorption through the roots.
The similar behavior regarding the removal of COD and FLO indicates that there is a common point that may be the inhibition of microorganisms after a certain time, causing the degradation of the antibiotic and other compounds that contribute COD to synthetic water to decline. Therefore, by exposing microorganisms for long periods of time to florfenicol, its bactericidal activity may have acted on the microbial population of the wetland, which generated inhibition in microorganisms, decreasing the efficiency of this treatment system after a certain time.

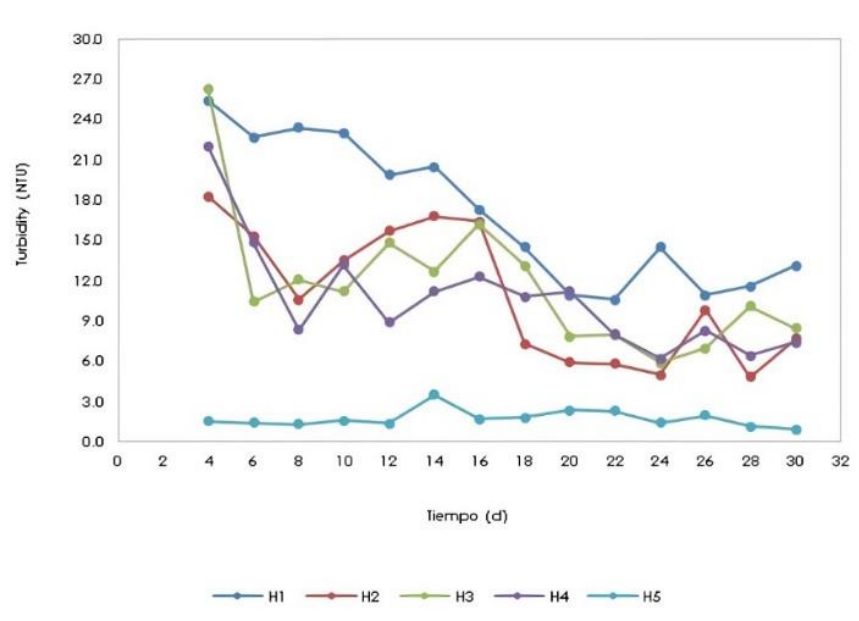

Figure 6. Behavior of turbidity in wetland effluents

According to Figure 7, the concentration that was used in $\mathrm{H} 4(25 \mathrm{mg} / \mathrm{L}$ FLO) strongly affected the microbial population, and this resulted in lower removal percentages of both florfenicol and COD. The concentration applied in the H2 wetland (15 mg/L FLO) favored the removal of both florfenicol and COD in the first days, indicating that for this concentration, microbial inhibition did not occur, and on the contrary, the microorganisms used florfenicol as a substrate for its metabolism, however, at the end of the treatment a slight inhibition begins to be noticed. The concentration evaluated in the $\mathrm{H} 1$ wetland (10 $\mathrm{mg} / \mathrm{L}$ of FLO) had a lower degradation kinetics than $\mathrm{H} 2$, this is due to the higher concentration of substrate, higher degradation kinetics. 
Comparing the removal of COD in the white wetland (H5), it is verified that florfenicol does influence the degradation kinetics of the synthetic water components and that in the long term it is possible that the microbial population present in the wetlands is affected from continuous exposure to florfenicol. The wetland that obtained the best FLO removal percentages was $\mathrm{H} 2$, with a maximum percentage of $77.9 \%$ and a minimum of $23.6 \%$. The $\mathrm{H} 1$ wetland had the lowest removal percentages, with a maximum value of $56.4 \%$ and a minimum of $4.7 \%$.

\subsection{Inhibition analysis}

A minin inhibitory concentration (MIC) analysis (Figure 8) was performed, in which all the concentrations of florfenicol used in the research $(10,15,20$ and $25 \mathrm{mg} / \mathrm{L})$ were analyzed, resulting in an inhibition minimal by the antibiotic for all concentrations evaluated; that is, the growth of the microbial population present in the wetlands was not significantly affected even with the maximum concentration evaluated $(25 \mathrm{mg} / \mathrm{L})$. These results are consistent with what was found in the removal percentages, where exposure to FLO in the first days resulted in high removal percentages, indicating little inhibition.

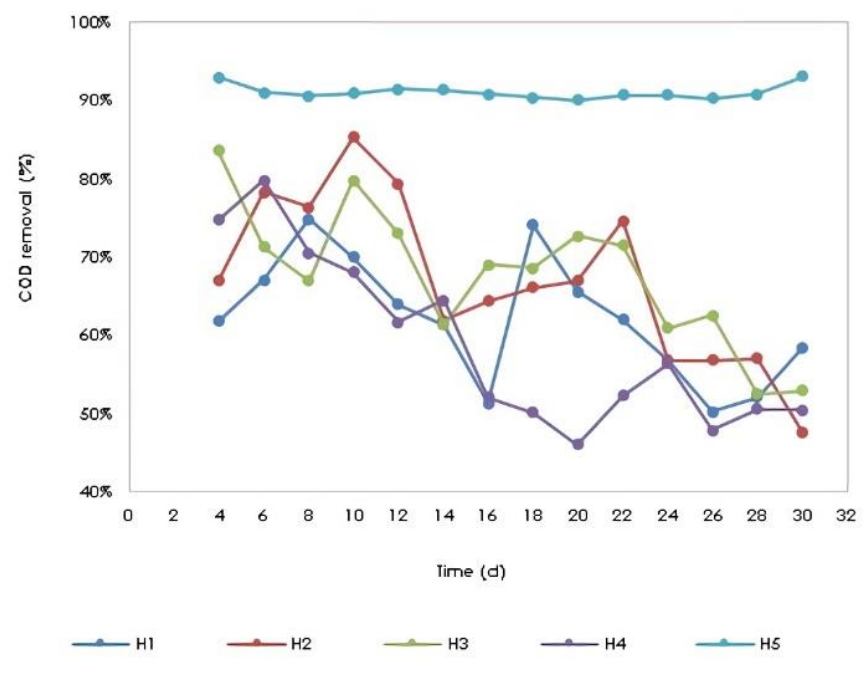

(a)

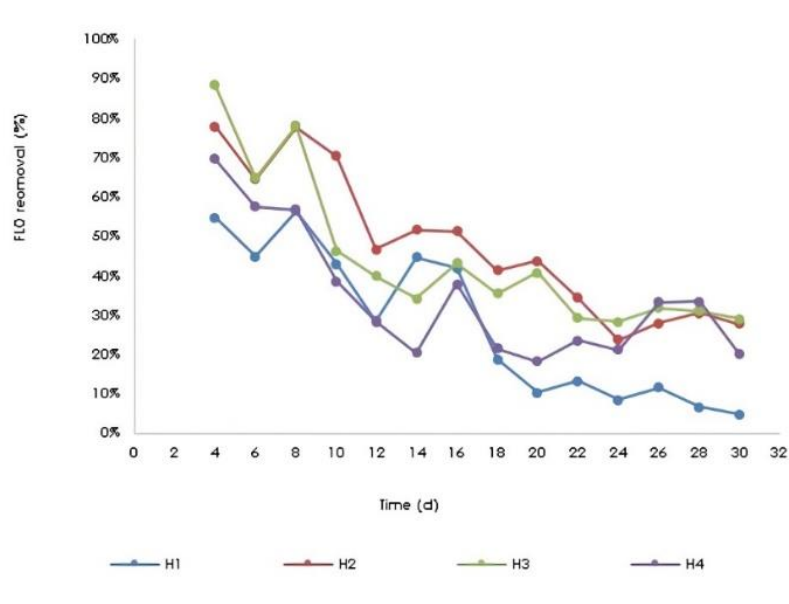

(b)

Figure 7. Behavior of removal rates in wetlands. a) COD. b) Florfenicol

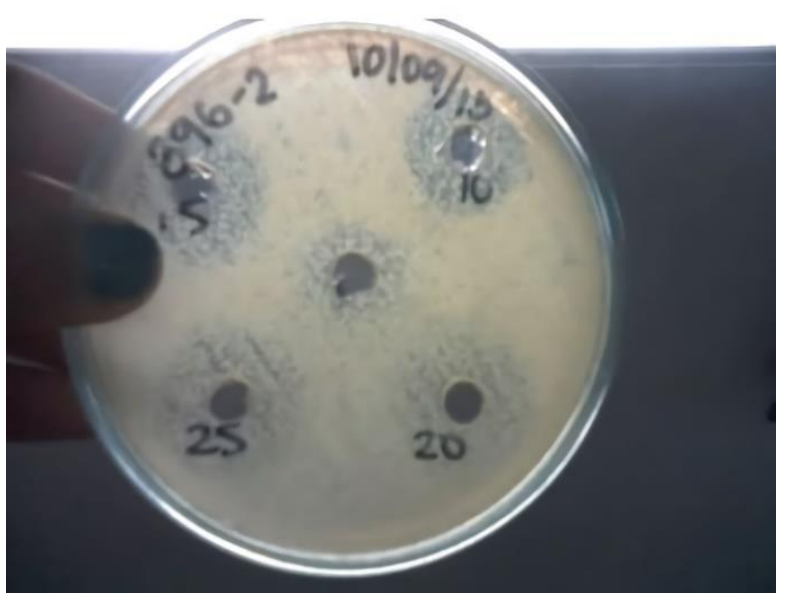

Figure 8. Bacterial inhibition test of the population in wetlands

\subsection{Plant material and gravel}

During the acclimatization and stabilization stage and at the end of the tests, heterotrophic microorganisms present in the gravel were counted (Table 1), in order to determine the microbial population present in each of the wetlands and evaluate the initial conditions prior at the entrance of these and ends, resulting in a high count of heterotrophic microorganisms in all wetlands at the beginning of the trials, and a relatively low decrease at the end, especially in wetlands $\mathrm{H} 1, \mathrm{H} 2, \mathrm{H} 3$ and $\mathrm{H} 4$, indicating that the 
presence of FLO, affected the heterotroph population, as evidenced by the removal percentages found.

Table 1. Heterotroph counting in wetlands

\begin{tabular}{c|c|c}
\hline Wetland & $\begin{array}{c}\text { Initial } \\
\text { CFU/g gravel }\end{array}$ & $\begin{array}{c}\text { Final } \\
\text { CFU/g gravel }\end{array}$ \\
\hline $\mathrm{H} 1$ & $3.40 \times 10^{5}$ & $3.01 \times 10^{5}$ \\
$\mathrm{H} 2$ & $2.80 \times 10^{5}$ & $1.80 \times 10^{4}$ \\
$\mathrm{H} 3$ & $2.60 \times 10^{5}$ & $1.30 \times 10^{4}$ \\
$\mathrm{H} 4$ & $2.50 \times 10^{5}$ & $2.10 \times 10^{4}$ \\
$\mathrm{H} 5$ & $3.50 \times 10^{5}$ & $2.20 \times 10^{4}$ \\
\hline
\end{tabular}

An analysis was carried out on the gravel at the end of the study, in which this granular material was extracted from the wetland with the highest concentration, and was placed under constant stirring for 1 hour with HPLC grade methanol, in order to extract all the FLO that was Present. The results showed a FLO concentration lower than the limit of quantification $(<5 \mathrm{mg} / \mathrm{L})$. Therefore, it could be ruled out that the FLO is interacting with the gravel (adsorptiondesorption), to the point that it has accumulated. Likewise, the plant material was analyzed at the end of the tests, the results, as well as the gravel, gave lower than the quantification limit $(<16.67$ $\mathrm{mg} / \mathrm{kg}$ ) in all the wetlands $(\mathrm{H} 1, \mathrm{H} 2 \mathrm{H} 3$ and $\mathrm{H} 4)$ and in all the parts of plant material. For this reason, it can be inferred that the FLO was not retained in some part of the macrophytes.

\section{Conclusions}

The decreasing behavior in the removal of florfenicol and COD was associated with a longterm inhibition of bacterial growth due to a prolonged exposure of the microorganisms to the antibiotic analyzed, where the wetland with the best removal of florfenicol was $\mathrm{H} 2$ ( $15 \mathrm{mg} / \mathrm{L}$ FLO) with a maximum of $77.9 \%$ removal the first days and a minimum of $23.6 \%$ after 30 days of operation of the wetland, therefore, it is concluded that when exposing the microorganisms to florfenicol, for prolonged times, inhibition processes occur, which reduces the removal efficiency of these processes and makes it necessary to couple this type of lowcost technologies with advanced processes that allow reducing the pollutant load prior to entering the wetland. The results found, allowed to show that florfenicol was not retained in the granular material of the wetlands, nor in the macrophytes, that is, no adsorption processes occurred, and that the predominant removal mechanism was biological degradation. The presence of plants in the wetlands (Phragmites australis) increased the turbidity in the effluents, due to the release of suspended solids and/or colloids, while the electrical conductivity in the effluents of the wetlands increased as a consequence of the biological processes carried out. carried out within these systems, in which organic matter is transformed into inorganic compounds. Finally, synthetic water with and without florfenicol had no relevant effects on $\mathrm{pH}$ and alkalinity, which was due to the buffering capacity of these treatment systems.

\section{Financing statement and acknowledgments}

The authors thank the Pollution Diagnosis and Control Group (GDCON: http://www.udea.edu.co/wps/portal/udea/web/ini cio/investigacion/grupos-

investigacion/ingenieria-tecnologia/diagnosticocontrol-contaminacion) of the Faculty of Engineering, Universidad de Antioquia, for funding this work. The funders had role in study design, data collection and analysis, decision to publish and preparation of the manuscript

\section{References}

(1) Yi XZ, Lin $\mathrm{CH}$, Ong EJL, Wang MZ. Occurrence and distribution of trace levels of antibiotics in surface waters and soils driven by non-point source pollution and anthropogenic

pressure.

Chemosphere. 2019;216:213-223. 
https://doi.org/10.1016/j.chemosphere.201 8.10.087.

(2) Hu P, Guo C, Zhang Y, Jiapei, L, Yuan Z, Jian $X$. Occurrence, distribution and risk assessment of abused drugs and their metabolites in a typical urban river in north China. Front. Environ. Sci. Eng. 2019;13(56):1-9. https://doi.org/10.1007/s11783-019-11405.

(3) Markets and Markets, Animal Antibiotics and Antimicrobials Market by Product (Tetracycline, Penicillin, Sulfonamide, Macrolide, Cephalosporin, Fluoroquinolone), Mode of Delivery (Premixes, Oral Powder, Injection), Animal (Food-producing \& Companion) Global Forecast to 2021. [cited 4 de mayo de 2020]. Available from: https://www.marketsandmarkets.co $\mathrm{m} /$ Market-Reports/animal-antimicrobialsantibiotics-market-25161353.html.

(4) Rasheed M, Bilal F, Nabeel M, Adeel H.M.N. Environmentally -related contaminants of high concern: potential sources and analytical modalities for detection, quantification, and treatment. Environ. Int. 2019;122:52-66. https://doi.org/10.1016/j.envint.2018.11.0 38.

(5) OIE. Lista de agentes antimicrobianos importantes para la medicina veterinaria. Comité Internacional de la Organización Mundial de Sanidad Animal, 75 ${ }^{\text {a }}$ Sesión General de mayo de 2007 (Resolución N ${ }^{\circ}$ XXVIII). 2019. p.1-9

(6) Park BK, Lim JH, Kim MS, Hwang YH, Yun HI. Pharmacokinetics of florfenicol and its metabolite, florfenicol amine, in dogs. Research in veterinary science.
2008;84(1):85-9.

https://doi.org/10.1016/j.rvsc.2007.04.001.

(7) Pouliquen H, Morvan ML. Determination of Florfenicol in Freshwater, Sediments and Bryophyte Fontinalis antipyretica by HPLC with Fluorescence Detection. 2005, 62(5): 225-231. https://doi.org/10.1365/s10337-005-06317.

(8) Carraschi S, Shiogiri N, Venturini F, Da Cruz C, Gírio ACF, Machado J. Acute toxicity and environmental risk of oxytetracyline and florfenicol antibiotics to pacu (Piaractus mesopotamicus), Boletim do Instituto de Pesca Sao Paulo. 2011;37(2):115-122.

(9) Wei R, Ge F, Chen M, Wang R. Occurrence of Ciprofloxacin, Enrofloxacin, and Florfenicol in Animal Wastewater and Water Resources. Journal of Environmental Quality. 2012.41(5):1481-1486.

https://doi.org/10.2134/jeq2012.0014.

(10) Bojarski B, Kot B, Witeska M. Antibacterials in Aquatic Environment and Their Toxicity to Fish. Pharmaceuticals. 2020;13(189):2-23. https://doi.org/10.3390/ph13080189.

(11) Hossain A, Nakamichi S, Habibullah-AlMamun, M, Tani K, Masunaga S, Matsuda H. Occurrence, distribution, ecological and resistance risks of antibiotics in surface water of finfish and shellfish aquaculture in Bangladesh. Chemosphere. 2017;188:329-336.

https://doi.org/10.1016/j.chemosphere.201 7.08.152.

(12) Wei ZS, Li WZ, D, Seo Y, Spinney R, Dionysiou DD, Wang Y, Zeng WZ, ,Xiao RY. Electrophilicity index as a critical 
indicator for the biodegradation of the pharmaceuticals in aerobic activated sludge processes. Water Res. 2019;160:10-17.

https://doi.org/10.1016/j.watres.2019.05.0

57.

(13) Matamoros V, Caselles A, García J, Bayona JM. Behaviour of pharmaceutical products and biodegradation intermediates in horizontal subsurface flow constructed wetland. A microcosm experiments. The Science of the total environment. 2008;394(1):171-176.

https://doi.org/10.1016/j.scitotenv.2008.01 .029 .

(14) Özengin N, Elmaci A. Removal of Pharmaceutical Products in a Constructed Wetland. Iran J Biotechnol. 2016;14(4):221-229. https://doi.org/10.15171\%2Fijb.1223.

(15) Nivala J, Kahl S, Boog J, van Afferden M, Reemtsma T, Müller RA. Dynamics of emerging organic contaminant removal in conventional and intensified subsurface flow treatment wetlands. Sci Total Environ. 2019;649:1144-1156.

https://doi.org/10.1016/j.scitotenv.2018.08 .339 .

(16) Anh BTK, Van Thanh N, Phuong NM, Nguyen YHH, Nhuyen HY, Bui Q, Dang DK. Selection of Suitable Filter Materials for Horizontal Subsurface Flow Constructed Wetland Treating Swine Wastewater. Water Air Soil Pollut. 2020;231(88):23-34. https://doi.org/10.1007/s11270-020-44496.

(17) Snow A, Bruce A, Wootton BC. Flowthrough land-based aquaculture wastewater and its treatment in subsurface flow constructed wetlands Environmental
Reviews. 2012;20(1):54-69.

https://doi.org/10.1139/a11-023.

(18) Dangcong P, Barnet N, Delgenes JP, Moletta R. Effect of oxygen supply methods on the performance of a sequencing batch reactor for ammonium nitrification. Water environment Research. 2000;72(2):195-200. https://doi.org/10.2175/106143000X13728 4.

(19) APHA, AWWA, WPCF. Standard Methods for the Examination of Water and Wastewater, 23th ed. Washington, DC. 2017

(20) Londoño YA, Rodriguez DC, Peñuela GA. The operation of two EGSB reactors under the application of different loads of oxytetracycline and florfenicol. Water Science \& Technology. 2012;66(12):2578-2585. https://doi.org/10.2166/wst.2012.485.

(21) Úsuga FA, Patiño AF, Rodríguez DC, Peñuela GA. Kinetic study and removal of contaminants in the leachate treatment using subsurface wetlands at pilot scale. Revista Ion. 2017;30(2):55-63. http://dx.doi.org/10.18273/revion.v30n22017005.

(22) Shimelis O, Ye M, Sidisky L. A New QuEChERS Dispersive SPE Material and Method for Analysis of Veterinary Drug Residue by LC-MS-MS. Sigma-Aldrich. 2011.

(23) Montoya JI, Ceballos L, Casas JC, Morató J. Estudio comparativo de la remoción de materia orgánica en humedales construidos de flujo horizontal subsuperficial usando tres especies de macrófitas. Revista EIA. 2010;14:75-84. 
(24) Álvarez S, Rico E, Guerrero MC, Montes C. Decomposition of Juncus maritimus in two shallow lakes of Doñana national park. Internat. Rev. Hydrobiol. 2001;86(45):541-554. https://doi.org/10.1002/15222632(200107)86:4/5\%3C541::AIDIROH541\%3E3.0.CO;2-T.

(25) Sánchez E, Marín J.L, Hernández M.E. Liberación de oxígeno radial por las raíces de las plantas nativas de humedales tropicales costeros de Veracruz en respuesta a diferentes condiciones de inundación. Botanical Sciences. 2019;97(2):202-210.

https://doi.org/10.17129/botsci.2069.
(26) Wiessner A, Kuschk P, Stottmeister U. Oxygen Release by Roots of Typha latifolia and Juncus effuses in Laboratory Hydroponic Systems. Acta Biotechnol. 2002;22(1-2):209-216. https://doi.org/10.1002/15213846(200205)22:1/2\%3C209::AIDABIO209\%3E3.0.CO;2-O.

(27) Asprilla WJ, Ramírez J.S, Rodriguez, DC. Humedales artificiales de flujo subsuperficial: comparación de metodologías de diseño para el cálculo del área superficial basado en la remoción de materia orgánica. Ingenierías USBMed. 2020;11(2):65-73.

https://doi.org/10.21500/20275846.4558. 